\title{
かご型誘導電動機の二次電流および トルクのセンシング
}

\begin{tabular}{|c|c|c|}
\hline 正 員 犬 & 塚 & \\
\hline 毛 & 利 & 佳年方 \\
\hline 正 員 & 田 & 誠 \\
\hline
\end{tabular}

\section{Sensing of Secondary Current and Torque of 3-Phase Squirrel Cage Induction Motors}

Katsumi Inuzuka, Member, Kaneo Mohri, Member (Nagoya University), Seiji Ishida, Member (Hitachi Ltd.)

In this paper, new experimental results for detecting $I_{2}$ and $T_{e}$ are reported using a magnetic-field sensor which is constituted with some amorphous microcores operating in a stable multivibrator followed by a low-pass filter.

The output of the sensor with eight pair of micro cores $\left(E_{\text {out }}\right)$ is proportional to $I_{2}$. The $E_{\text {out }}$ has not only a voltage component of the frequency $f$ but also components of frequency $s f, f n-s f$, $f n+s f$ and others when a sensing with only one pair of microcores, where $s f$ is a slip frequency, $f n$ is a rotor speed frequency, $f(1-s) / 2$. It causes the components $f n \pm s f$ that the rotor performs a precession motion. The voltage component of the $f n-s f$ was proportional to $T_{k}$.

A calculated torque $\left(T_{m}\right)$ using the measured value of $I_{2}$ almost coincides to a measured torque $\left(T_{e}\right)$ using a DC generator which is a load of IM.

キーワード：アモルファス磁界センサ，二次電流センサ，二次電流検出，トルク检出

\section{1.はじめに}

現在，工業用口ボットや工作機械，エレベータ，制 鉄用圧延機などの制御の高度化，知能化を進めるため に、モータ制御の高精度化の必要性がますます高まつ てきた。従来, モー夕制卸分野では, 励磁磁束と電機 子電流とを独立に制御できる直流電動機（以下， DCM と略記）が主流であった。しかし，DCMには ブラシの摩耗による低信頼性や保守の必要性, ブラシ からの火花の電磁雑音の発生による他の電子機器の 誤動作などの問題がある。かご型誘導電動機（以下，

IM (路記) は, ブラシレスでメンテナンスフリーで あり，構造が簡单で堅固，更に低価格で取扱いが容易 である。佂って，DCMをIM に置き換える動きがす う勢となっている。IMの制御は，IMに滑りが存在
するため，古典的手法では，DCMに比べて签易では なく，また制御精度は低く，制御範囲は狭かった。こ れに対して, 最近電力変換器やマイクロコンピュータ などの発達や、ベクトル制御いなどの手法によって IMのDCMなみの制御が可能になった。しかし，IM のトルクは温度によって変化する二次抵抗（回転子抵 抗） $r_{2}$ に依存しているため，IMの運転中にトルクは IM内の温度上笔と共に大きく変動（例えば， $100^{\circ} \mathrm{C}$ の温度上昇で 20 - 30\%変動) し, 制御詥差となる。従 って，IMのトルクの高精度制御には $r_{2}$ の温度補償を 行う必要があるが，これは未解決の問題として残され ている。 $r_{2}$ 温度補償の問題を解決する画接的な方 法は二次電流 $I_{2}$ またはトルク $T_{e}$ を楧出する方法であ る。この $I_{2}$ まは $T_{e}$ のセンサ出力を帰還する制御系 は $r_{2}$ の温度変動の影響を受けないことになる。 


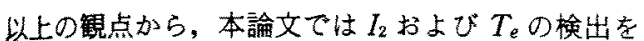
行うことを目的として，次の方法を用いた。

(1) IM 内の温度変化 $\left(-50^{\circ} \mathrm{C} \sim 180^{\circ} \mathrm{C}\right)$ に上ら ず安定で直線性，周波数特性の良いアモルファス二磁 らマルチバイブレータ形磁界センサを構成する(2)。

(2) IMのロー夕 (回転子) のエンドリング近傍 にアモルフアス磁心を設置し， $I_{2}$ に比例する磁界を検 出する $\left(I_{2}\right.$ の非接触検出)。

(3) アモルファス磁心はロー夕の再側 4 简所ずつ 計 8 筒所に設置し，ロータの半径方向やシャフト軸方 向の機械的振動の影響を相段して $I_{2}$ を检出す $ろ^{(3) \sim(5)}$ 。この際，七ンサ取付けフレームの振動の影 響が出ないように，図2のようにアルミ細板の長さを 短䌅した。

(4) $V / f$ 一定方式のインバータドライブでは, T は $I_{2}$ に比列するので, $T_{e}$ が㛟出される。

(5) $T_{e}$ のほ加の検出法として, ロータのエンド リング近傍にアモルファス磁心を1箅所ないし2箅所 設置し，エンドリング電流およむ゙ロータ回転振動に伴 うセンサ出力口周波数スペクトル成分より $T_{e}$ 韭接 触䧀出する。

（1）（ 5 ）を実施した結果，（3）では励磁周波数の I を検出することができた。更に（5）により滑り周 波数の $I_{2}$ 拉よび $T_{e}$ に正比列するスペクトル成分を検 出することができだ。

\section{2. 二次電流センサ}

本諭文で用いた $I_{2}$ センサには， $I_{2}$ により発生する 磁界を椮出する磁界ゼンサを用いた。この磁界センサ は図1に示すように，直径 $125 \mu \mathrm{m}$, 長さ $6 \mathrm{~mm} の$ 雺 柕歪アモルファスワイヤを磁心とした声径 $2 \mathrm{~mm}$ ，長 さ $5 \mathrm{~mm}$ のコイル対をもつマルチパイブレータによ り，高速応答形磁界センサを構成した。図 2 に示すよ うに，そのアモルファス磁心をロータのエンドリング 近傍に設置し，非接触检出を行っている。この磁心に 零磁歪アモルファスワイヤを用いることで, 振動によ

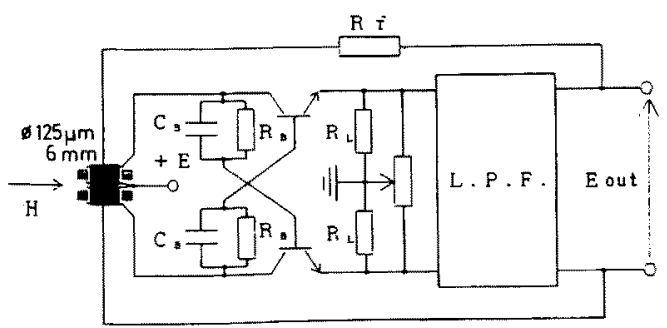

図 1 マルチバイプレータ形磁界センサ

Fig. 1. Multivibrator type field sensor.

疍学㫻D, 112 巻 9 号, 平成 4 年
る応力の影響を少なくしている。また，センサ回路は 負惕還構成にすることにより，図３に示すように $-196^{\circ} \mathrm{C} \sim 180^{\circ} \mathrm{C}$ 温度変動に対して感度が定であ り，直線性も十分に高い高精度の磁界センサとしてい る(6)。更に，図4に示すようにアモルファス磁心をロ 一タの両側に複数組設置 $\left(1-1^{\prime} \cdots 8-8\right)$ することで,

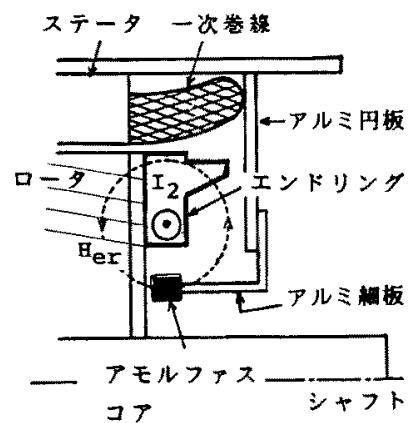

図 2 アモルファス磁心の設䈯埸所

Fig. 2. Position of amorphous cores.

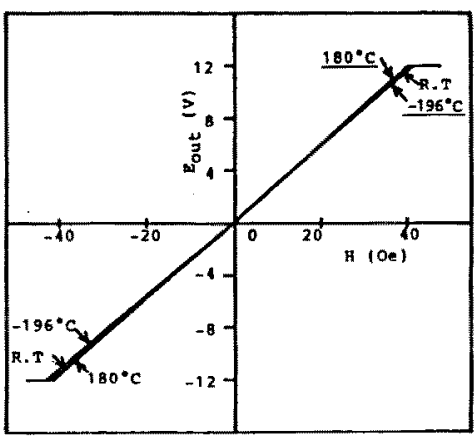

図 3 磁界检出特性

Fig. 3. $E_{\text {out }}$ vs. $H$ characteristics.

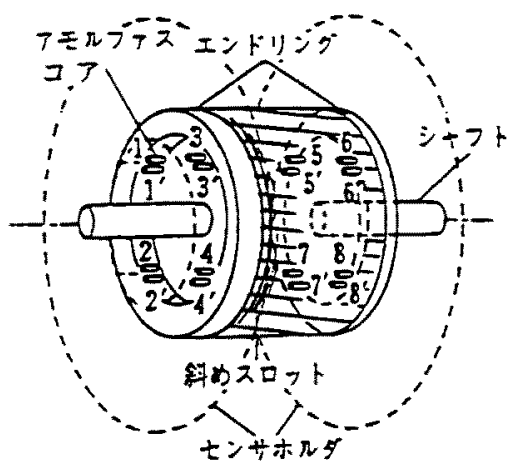

图 4 アモルファス磁心の配置

Fig. 4. Location of amorphous cores. 
後述のようにロータの軸方向や半径方向の振動による センサ出力への影響を相殺している。このセンサ全体 の遮断周波数は $66 \mathrm{kHz}$ (マルチバイブレータの発尉 周波数は $1 \mathrm{MHz}$ )であり，インパータでIMを運転 する場合, トランジスタのスイッキング周波数の 5 〜10倍であるので, IM のインバー夕の運転において も $I_{2}$ 波形をゆがませずに検出するには十分な周波数 である。

\section{3. 二次電流の検出}

図 5 は, 4 極, $1.5 \mathrm{~kW}$ の IM を, 商用電源三相 $200 \mathrm{~V}$, 定格負荷で運転し，エンドリング近傍に 1 筒 所または 8 筬所のアモルファス磁心を設置した $I_{2}$ 検 出波形，およびその FFT シグナルアナライザによる 周波数スペクトラムを示す。センサの磁心忏固定子側 に設置してあるため, 検出波形は励磁周波数の交流と なる。磁心 1 箇所でのセンサ出力波形には, 励磁周波 数成分の注加数 $\mathrm{Hz}$ の低周波成分と励磁周波数未満 の周波数成分とを含んでいる。磁心 8 䈏所の場合には これらの低周波数成分はなく，8箅所の磁心によって ロータの軸方向や半径方向の振動成分などが相殺され ていることがかかる。

また, インバータでIMを $60 \mathrm{~Hz} て ゙$ 渾転した場合の $I_{2}$ センサの検出波形を図 6 に示す。トランジス夕のス イッチングによる高調波の成分も検出していることが わかる。図 7 は $I_{1}$ (一次電流)をパラメー夕とした $I_{2}$ センサの $I_{2}$ 検出特性である。横軸の $I_{2}$ の值はIMの 負荷として使用している直流発電機 (DCG) の出力 と回転計の値による次式のトルク $T_{m}$ 加算出した。

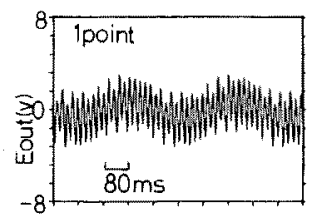

(a) 1-point sensing

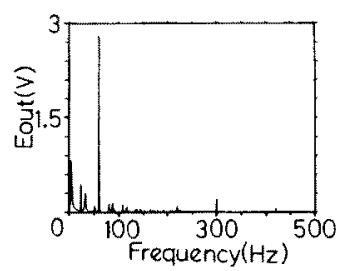

(c) Spectrum(1-point)

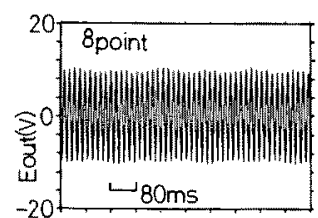

(b) 8-point sensing

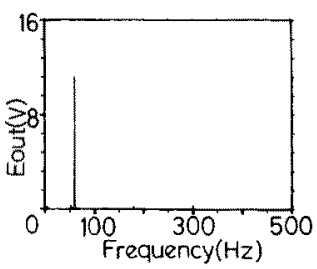

(d) Spectrum (8-point)
図 5 片センサによる $I_{2}$ の検出

Fig. 5. $I_{2}$ sensing using amorphous sensors.
$T_{m}=\frac{E_{D C} I_{D C}+r_{a} I_{D C}^{2}}{\pi N} 30$

ただし， $E_{D C}: D C G の$ 端子電圧, $I_{D C}: D C G$

の線電流, $r_{a}: \mathrm{DCG} の$ 巻線抵抗, $N: \mathrm{IM} の$ 回転数

更に $I_{2}$ は $T_{m}$ を用いると次式で表される。

$I_{2}=k \sqrt{\frac{4 \pi s f T_{m}}{3 p r_{2}}}$

たたし， $s:$ 滑り，p：極数， $r_{2}$ : 二次抵抗，

$f:$ 励磁周波数, $k:$ 固定子側と回転子側と

の結合係数

この $k$ は不明なので，各図の横軸は $k$ で除した值を 用いた。 $I_{2}$ の式には $r_{2}$ の項が含まれているが， $r_{2}$ の 值は室温の值を用い， $r_{2}$ が変化しないように短時間 で実験を行った。このように，I $I_{2}$ 正比例したセンサ 出力が得られ， $I_{2}$ 検出されていることがわかる。

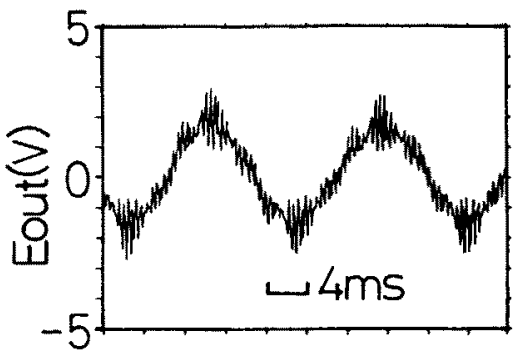

図 $6 I_{2}$ センサによる $I_{2}$ の検出 (インパー夕運転)

Fig.6. $I_{2}$ sening (inverter).

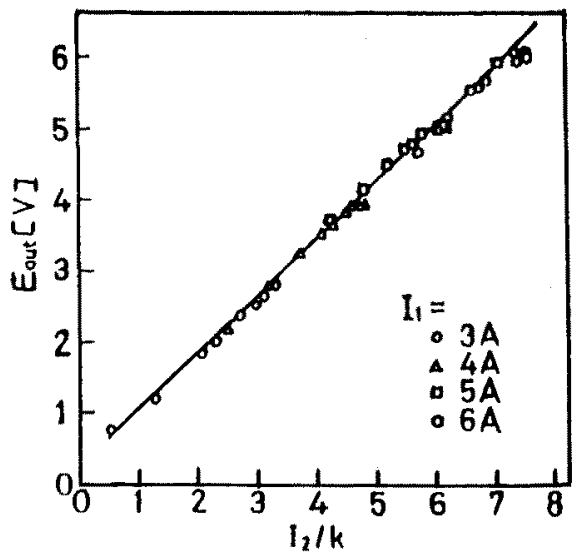

図 $7 I_{2}$ 検出特性（商用電源）

Fig. 7. $E_{\text {out }}$ vs. $I_{2}$ characteristics (commercial power supply). 


\section{4. 二次電流の低周波数成分解析}

図5（c）の磁心 1 箇所のスペクトラムには，10 Hz 未満の成分が励磁周波数 $(60 \mathrm{~Hz})$ についで大きく， そのほかにも $30 \mathrm{~Hz}$ 付近の 2 成分当大きいことがわ かる。無負荷から定格貫荷までのスペクトラムの变化 を図 8 に示す。この3成分のピーク周波数は急荷の大 きさによって移動していることがわかる。この3成分 の周波数をIM の回転速度に関する值である滑り周波 数 $s f(\mathrm{~Hz})$ ，回転速度 $f n(\mathrm{~Hz})$ を用いて表すと，図 9 に示すように，それぞれ $s f$, fn士sfを示すことがわ かった。この3成分の発生原因がロ一タの振動成分で あると仮定し，以下に述べるような磁心の配置につい ても同様な測定を行った。IM駆動電源は商用電源お よびV/f一定のインバー夕 $(60 \mathrm{~Hz})$ である。図 4 に 示す磁心の配置において，

(1) IM の左側のビれか1箇所（1 point）

(2) IMの右側のどれか 1 箇所（1 point）

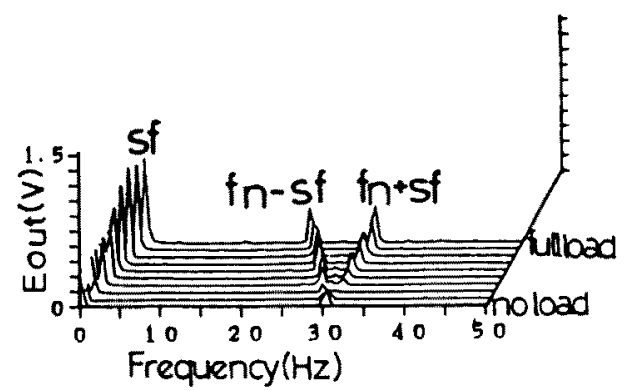

図 8 負荷によるスペクトラムの変化

Fig. 8. Variation of spectrum by loads.

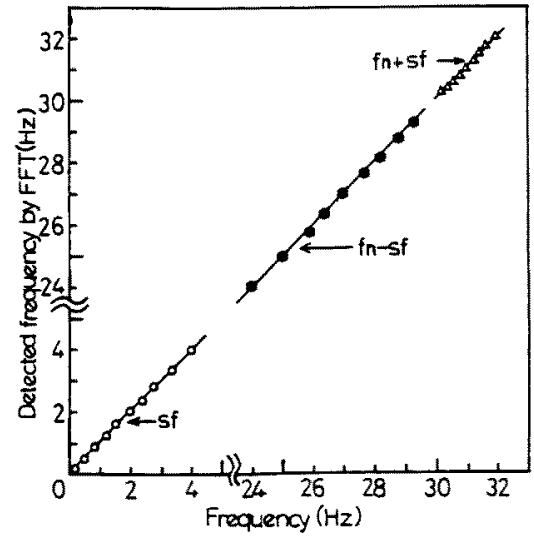

図 9 周波数検出特性

Fig. 9. Measured $f$ vs. $f$ characteristics.
(3) IMのシャフトに詨して平行になるように1$1^{\prime}$ と5-5，2-2'と6-6 0 ような組合せて 2 簓所 $(2$ point)

(4) IM の左側の磁心 4 䈏所 (4 point)

(5) IM の右側の磁心 4 䉒所 (4 point)

(6) 全磁心 8 筒所 (8 point)

の計 6 通りの配置で測定を行った。本実験のシステム を図 10 に示す。実験には図 5 の場合と同じ $1.5 \mathrm{~kW}$, 4 極のIM を用い，IMの右側を急荷側 $(L)$, 左叟を 自由側 $(F)$ とする。1䇫所，負荷側の磁心を用いた ときのsf, $f n \pm s f$ 各成分の大きさの関係を商用電 源で運転した場合について測定を行った。

6 種類の point に上る $s f$ ，fn士sf 成分の検出度を， 励磁周波数成分に対する割合にして表 1 に示す。1 point $の L$ 側は $s f, f n \pm s f$ 成分とも最大であった。1 point $\emptyset F$ 側 22 point 共 $s f, f n-s f$ 成分を検出し ているが，他の pointではほとんど模出されていない のがわかる。この周波数成分は, 磁心の配置から， IMの負荷側のシャフトに対して垂直方向（ロータの 半径方向）の振動が原因と考えられる。考た，4 point と8 point による检出は励磁淍波数成分に比心゙, それ以外の周波数成分はほとんど検出されていない。 従って， I により、ロータの振動などの影響を受けることなく検 出することがでるる。

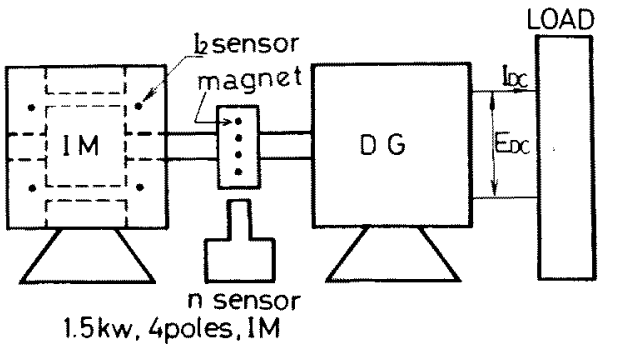

园 10 実験システム

Fig. 10. Systems for experiments.

表 1 各 point 0 蚞出周波数の蚞出度 Table 1. Sensing frequency ratio of each point.

\begin{tabular}{c|c|c|c|c|c|c}
\hline Frequency & $1 L$ & $1 F$ & 2 & $4 L$ & $4 F$ & 8 \\
\hline$s f$ & 0 & 0 & 0 & $\times$ & $\times$ & $\times$ \\
\hline$f n-s f$ & 0 & $\Delta$ & 0 & $\times$ & $\times$ & $\times$ \\
\hline$f n+s f$ & 0 & $\times$ & $\Delta$ & $\times$ & $\times$ & $\times$ \\
\hline
\end{tabular}

$0: 0.1 \sim 0: 0.02 \sim 0: 0.01 \sim \quad x:-0.01$ 


\section{5. 定常トルクの検出}

〈5・1〉 I $I_{2}$ センサによる定常トルクの検出 IM の安定領域（骬りとモータのトルクとがほほ正比例す

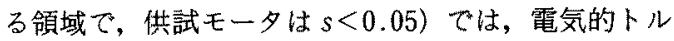

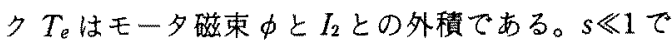
は $L$ 形等価回路により，近似的に次式で表される。

$$
T_{e}=\Phi \times I_{2} \fallingdotseq \frac{\sqrt{3} p V I_{2}}{4 \pi f}
$$

$こ こ に, p:$ 極数, $V:$ 一次線間電圧, $f$ :

励磁周波数

(3)式は $r_{2}$ を含まないので， $I_{2}$ を検出することに より $T_{e}$ が温度変動に影響を受けることなく検出され る。図11に(3)式による $T_{e}$ の測定值と，(1)式に よる $T_{m}$ の測定值との関係を示す。両者は正比例して おり，Teが正確に検出できることを示している。

図 12 は，IM を定格負荷で 1 時間連続運転した場

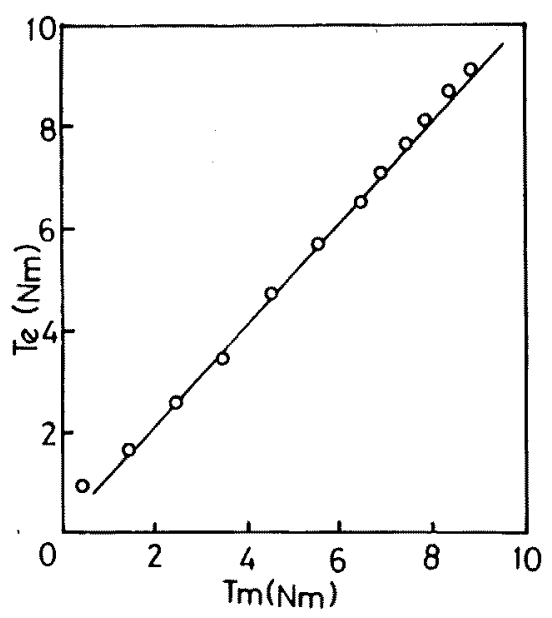

図 11 定常トルク㭘出特性

Fig. 11. $T_{e}$ vs. $T_{m}$ characteristics.

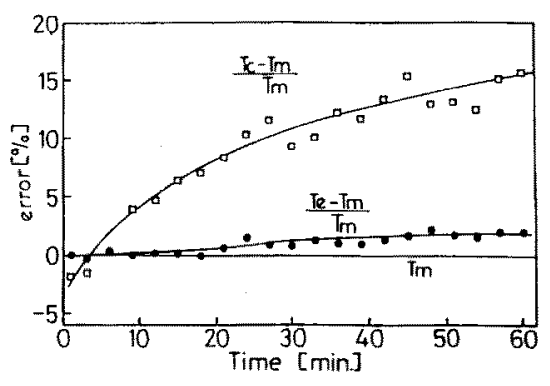

図 12 各計算法による誤差の時間変化

Fig. 12. Time variation of errors.
合の $T_{e}$ と $T_{m}$ 㧍よび， $I_{2}$ を含まない $L$ 型等価回路加 ら求められる次式のトルク $T_{c}$ と $T_{m}$ との関保を測定 した結果である。

$$
T_{c} \fallingdotseq \frac{p V^{2} s}{4 \pi f r_{2}}
$$

トルクの真值を $T_{m}$ とすると, $T_{e}$ と $T_{m}, T_{\mathrm{c}}$ と $T_{m}$ の相対䛇差は，IMの定格負荷運転において，前者梳 $2 \%$ 以内, 後者は $15 \%$ に達している。従って, $I_{2}$ セ ンサにより， $T_{e}$ がロータの温度の影響を受けずに梌 出されていることがわかる。 $T_{e}$ と $T_{m}$ との相対誤差 の上昇傾向は IM 60 分間連続運転したため, 直流 発電機内の温度が上昇し, $r_{a}$ の值が変化したためと考 えられる。

\section{〈5・2〉 $f n-s f$ 成分による定常トルクの検出}

アモルファス磁心を 1 䈉所以設置した場合の磁界せ ンサの出力電圧 $E_{\text {out }}$ のうち, $f n-s f$ 成分を $E_{\text {out }}(f n$ -sf) とすると, $60 \mathrm{~Hz}$ 正弦波励磁 ( $I_{1}$ パラメー夕) における $E_{\text {out }}(f n-s f)$ のトルタ $T_{m}$ に対する特性が图 13 の上うに得られた。この図は $E_{\text {out }}(f n-s f)$ が $T_{m}$ に正比例の関係を示している。従って, $T_{e}$ を $E_{\text {out }}(f n$ 一sf)によって直接蚞出できることがわかった。 $s f$ お 上び $f n+s f$ 成分はいずれも $T_{m}$ との比例性は示さな

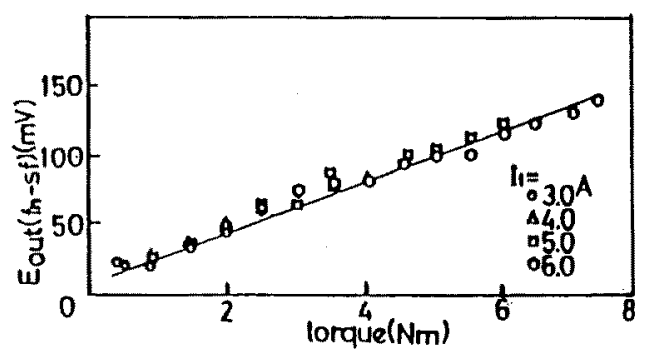

図 13 トルクー $E_{\text {out }}(f n-s f)$ 特性

Fig. 13. $E_{\text {out }}(f n-s f)$ vs. $T_{m}$ characteristics.

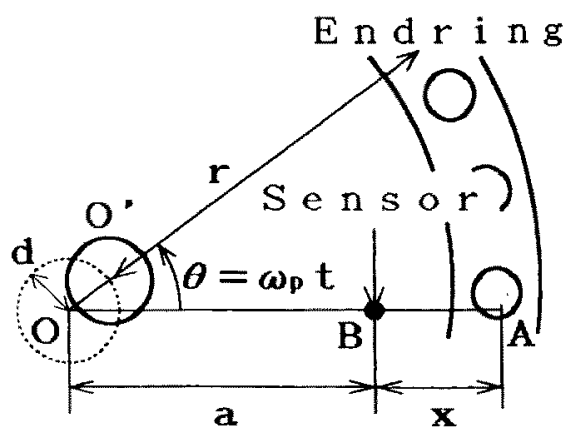

図 14 歳差運動をするロータ

Fig. 14. Precession motion of rotor. 
かつた。

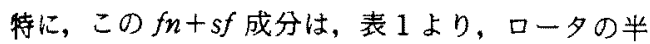
径方向の振動であり，L側の 1 point で大きく検出さ れていることから、ロータがモータの回転軸のまわり をロータと同じ回転速度 $\omega=2 \pi f n$ で歳荎運動をする のが原因と考えられる。图 14 のように、ロータの中 心 $O^{\prime}$ とロータバーの中心との距離を $r$, ロータの真 ふり半径をd，センサとエンドリングとの距離索 $x$, モータの中心軸 $O$ と七ンサ位置 $B$ との距﨎を $a$ とす る。そして $O^{\prime} O$ と $O A$ とのな角が $\theta$ てあるとき， $d \ll r-a$ と仮定すると，距離 $x$ 峙次式で与えられる。

$$
x=r-a+d \cos \omega_{L} t
$$

ロータが歳差連動をするとき，ステータから見た 12 を $I_{2}=I_{2 m} \sin \omega_{1} t$ とすると，七ンサ検出電压 $E_{\text {out }}$ 岋 次式になる。

$$
\begin{aligned}
E_{\text {out }}= & k \frac{I_{2}}{2 \pi x} \\
= & E_{1} \sin \omega_{1} t-\frac{d E_{1}}{2 \pi(r-a)} \\
& \times\left\{\sin \left(2 \pi f_{+} t\right)+\sin \left(2 \pi f_{-} t\right)\right\}
\end{aligned}
$$

ただし，k：センサ感度， $2 \pi f_{+}=2 \pi\left(f_{1}+f_{L}\right)$

$=\omega_{1}+\omega_{L}, 2 \pi f_{-}=2 \pi\left(f_{1}-f_{L}\right)$

$E_{1}$ は次式で表される。

$$
E_{1}=\frac{k I_{2 m}}{2 \pi(r-a)}
$$

(6)式の第 2 項が歳荎運動による出力電圧成分であ る。ロータのエンドリングに二次電流 $I_{2}$ が流れたと 茟，ステー夕側から見た $I_{2}$ の正相分の周波数成分 $f_{1}$ は $f$ で表される。更に，ロータバーのインピーダン スが不平衡であるとき，I2の逆相分も存在する。その 逆相分をステー夕溉から見たとき，その周波数成分 $f_{1}$ は $f(1-2 s)$ で表される。ロータが，

$$
f_{L}=f n=\frac{2}{p} f(1-s) \quad(s: \text { 滑り })
$$

で表されるロータの回転速度で歳差連動をすると仮定 すれば，正相，逆相分それ㞦加得られるf-成分 に $f_{1}, f_{L}$ および本研究で用いたIMの極数 $(p=4)$ を代 入すると正相分では(8)式が，逆相分では(9)式が得 られる。

$$
\begin{aligned}
& f_{-f}=\frac{f}{2}(1-s)+s f=f n+s f \\
& f_{-r}=\frac{f}{2}(1-s)-s f=f n-s f
\end{aligned}
$$

つまり, 回転速度 $f n$ と滑 $り$ 周波数 $s f と の$ 和, 差の 成分が检出される。
このロータの㛶差運動は，ロータのシャフト軘に対 して平行な力が不平衡に㗢いているのが原因である。 ロータバーに働く力は，ロータパーに対して垂直方向 に向く。ロータバーはシャフト方向に対してある角度 (スキュ一角) たけ傾いている。このスキュ一角は， ロータバーに発生した力をシャフトに対して茟直な成 分と平行な成分（シャフト軸成分）とに分割する。垂 直成分は，モータのトルクとなってロー夕を回転させ る。シャフト㷁成分は，ロータがシャフト蟿に対して 平行方向に押される力になる。この力のシャフト軸成 分がエンドリング上で不平衡に発生していれば，この 力のベクトル的総和はエンドリングの一部だけに現 れ，シャフト軸方问に働き，ロータを傾かせるような トルクになる。このトルクが, ロータに歳差隀動をさ せる原因になる。

そしてその力のシャフト軸成分の不平衡の原因は， ロータバーのインピーダンスが各々翼なっていること である。そのインピーダンスがすべて等しいとすれ ば，バーに発专する力はモータ回転軸に関して軸対称 に分布するので，ロータを傾けさせるようなトルクは 発生しない。しかし，インピーダンスが異なるとき， 各バーに発生する力のシャフト軸成分の総和はゼロに はならない。つまり，ロー夕を傾かせるようなトルタ が働き，ロータに藏差運動をさせる原因になる。そこ で著者らは，ロータバーのインピーダンスが同じでは ないときに、ロータに歳差連動をさせるトルクを計算 するシミュレーションを行った。そのときの各バーの インピーダンスの分布は正規分布に從う值にした。そ の結果，このトルクについて次のようなことがわかっ to

(i) エンドリング上の一点に集中して働いている と等洒である。

(ii) 常に一定値になっている。

つまり（（i）結果よりこのトルクの軸方向成分は口 一タの回転速度と一緒に回転していることである。従 って，ロータはこのトルタによってシャフト軸方向に 引つ張られ，ロータの回転速度を同じ速度で藏差運動 をする。って，I2センサには(8)，(9)式に示され る周波数が検出され，更に(6)式上り周波数 $f_{+}, f_{-}$成 分の振幅が，ロータの首振り半径 $d$ に比例すること になる。このdが単純にモータのトルクに比例すれ ば， $f_{+}, f_{-}$の両成分がトルクに比例する。しかし， $f_{+}$ 成分の振幅との関係は，実験結果と異なるため，IM と負荷とのジョイン゙トなどの原因も関係していると考 えられる。 


\section{6. まと め}

アモルファス磁心マルチバイブレータ形磁界センサ をIM のエンドリングの近傍に設置し，エンドリング の二次電流を検出し，その電流の周波数スペクトルお よびトルクの検出を行い, 次の結論を得た。

（1）エンドリング近傍に設置した磁界センサは二 次電流 $I_{2}$ を検出し, 磁心を 8 箇所に設置すれば, 口 一夕の振動による雑音が相殺され, 正確な二次電流検 出ができる。

（2）磁心 1 箇所で検出を行った場合, 励磁周波数 成分のほかに滑り周波数 $(s f)$ 成分, $f n-s f$ 成分, $f n+s f$ 成分が検出され, $f n-s f$ 成分はトルクに比例 している。そして, $f n \pm s f$ 成分はロータの歳差運動 によって発生する。このセンサに $20 \sim 30 \mathrm{~Hz}$ の帯域 フィルタを用いれば, 温度変化の影響を受けないトル クの検出も可能になる。

（3）二次電流センサの出力電圧と一次線間電圧と の積を用いれば，温度の影響を受けないトルクの正確 な検出ができる。

(平成 4 年 1 月 27 日受付)

$$
\text { 文献 }
$$

(1) F. Blaschke: "Das Prinzip der Feldorientierung, die Grundlage fur die Transvectorregelung von Drehfeld Mas chienen", Siemens $Z$., 45, 757 (1971)

(2) K. Mohri: "Review on Recent Advances in Field of Amorphous-Metal Sensors and Transducers", IEEE Trans. Magnetics, MAG-20, No. 5, 942 (1984)

(3) K. Mohri, M. Nakano, Y. Mukai \& Y. Yoshida: "Detec tion of Secondary Current and Torque of Induction Motors Using Amorphous Micro Core Field Sensors" ibid., MAG-22, No. 5, 397 (1986)

（4）吉田・毛利・近藤：「アモルファス磁界センサによるかご型 誘導電動機発生トルクの検出」, 電学論 B, 105, 973 (昭 60)

（5）毛利・中野・向井・吉田:「アモルファス磁界センサによる ご型誘導電動機の二次電流およびトルクの検出」, 電学論 D, 107, 57 (昭 62-1)

（6）向井・若山・毛利・奥田・小笠原：「負帰還アモルファス多
磁心マルチ型電流センサの耐外乱特性」, 応用磴気学誌，12 No. 2, 399 (昭 63)

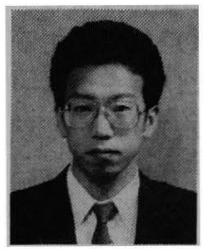

犬塚 勝美 (正員)

昭和 42 年 9 月 3 日生。平成 2 年 3 月 東京農工大学工学部電気工学科卒業。同 年 4 月名古屋大学大学院工学研究科電気 工学専攻修士課程入学, 現在に至る。誘 導電動機の計測と制御との研究に従事。

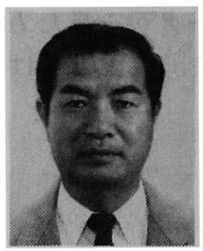

\section{毛 利 佳年雄（正員）}

昭和 15 年 11 月 16 日生。 43 年 3 月九 州大学大学院工学研究科博士課程修了。 57 年 4 月九州工業大学電気工学科教授 (電力制御半導体工学講座)。62 年 10 月 名古屋大学工学部電気学科教授 (電気機械器具講座), 現 在に至る。工学博士。主として,アモルファス磁性体と磁 気センサへの応用, 誘導電動機のビルトインセンサによる 計測制御, 生体微振動情報, 高温超電導磁気応用などの研 究に従事。5 5 年市村賞, 平成元年日本応用磁気学会論文 賞受賞。電子通信情報学会, 日本応用磁気学会, 計測自動 制御学会, IEEE 会員。

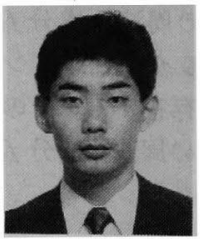

石田誠司 (正員)

昭和 40 年 11 月 29 日生。平成 2 年 3 月名古屋大学大学院工学研究科電気工学 専攻修士課程修了。同年 4 月 (株) 日立製 作所入社。現在に至る。 